\title{
Economics of Sorghum - Chickpea Cropping System as Affected by Integrated Nutrient Management (INM) under Rainfed Conditions
}

\author{
Seema M. Nemade ${ }^{1}$, N. B. Mohod ${ }^{2}$, G. J. Bhagat ${ }^{1}$, V. R. Thakur ${ }^{1}$, \\ D. T. Dhule ${ }^{1}$ and M. M. Ganvir ${ }^{1}$ \\ ${ }^{1}$ College of Agriculture, Dr P.D.K.V.Akola, India \\ ${ }^{2}$ Department of Agronomy Dr.P.D.K.V.,Akola, India \\ *Corresponding author
}

\author{
A B S T R A C T
}

\begin{tabular}{|l|}
\hline Ke y w o r d s \\
Yield, Economics, \\
$\begin{array}{l}\text { INM, Sorghum- } \\
\text { Chickpea, Cropping } \\
\text { Sequence }\end{array}$ \\
\hline Article Info \\
\hline $\begin{array}{l}\text { Accepted: } \\
\text { 25 February } 2020 \\
\text { Available Online: } \\
\text { 10 March } 2020\end{array}$ \\
\hline
\end{tabular}

A field experiment on Integrated Nutrient Management in sorghum-chickpea cropping system was conducted to identify an ideal integration of organic and inorganic nutrient sources for getting maximum yield and monetary benefit with minimum input cost. The experiment on sequence of kharif sorghum and rabi chickpea was conducted during kharif season of 2013-2015 at the farm of Sorghum Research Unit(CRS) Dr.PDKV,Akola The experiment was conducted in RBD with the nine nutrient management treatments in Kharif for sorghum which were T1-100\% RDN through inorganic fertilizer,T2-50\% RDN through inorganic fertilizer+50\% RDN through FYM ,T3-75\% RDN through inorganic fertilizer+25\% RDN through FYM ,T4-50\% RDN through inorganic fertilizer $+50 \%$ RDN through vermicompost ,N5:75\% RDN through inorganic fertilizer $+25 \%$ RDN through vermicompost,T6-50\% RDN through inorganic fertilizer+25\% RDN through FYM+25\% RDN through vermicompost,T7-75\% RDN through inorganic fertilizer $+25 \%$ RDN through FYM+ seed treatment with microbial fertilizers PSB+ Azospirillum, T8-75\% RDN through inorganic fertilizer $+25 \% \mathrm{RDN}$ through vermicompost+ seed treatment with microbial fertilizers PSB+ Azospirillum,T9-75\% RDN through inorganic fertilizer + seed treatment with microbial fertilizers PSB+Azospirillum. Whereas chickpea was gown on the same randomization without application of fertilizers in rabi. The integration of organic and inorganic fertilizers were superior to inorganic treatments alone for both crops in sequence. Application of $75 \%$ RDN through inorganic fertilizer+ 25\% RDN through FYM + seed treatment with PSB + Azospirillum to kharif sorghum and growing rabi chickpea without recommended dose of fertilizer recorded higher economic returns and B:C ratio of sole crop as well as system. This might be as a result of higher grain and fodder yield of sorghum as well as chickpea with the same treatment.

\section{Introduction}

Continuous use of only chemical fertilizers impure soil health reduces crop inputs responses and is not able to sustain crop productivity. Research evidences showed that integration of biological sources of nutrients with limited chemical fertilizers may be helpful in improving soil health and sustaining the crop productivity. INM is the most efficient and practical way to mobilize all the available, accessible and affordable plant nutrient sources in order to optimize the productivity of the crops/cropping systems and economic return to the farmer. A comprehensive literature search revealed that 
INM enhances crop yields by $8-150 \%$ compared with conventional practices, increases water-use efficiency, and the economic returns to farmers, while improving grain quality and soil health and sustainability (Wei Wua and Baoluo Ma,2015).

Besides nutrients availability, FYM also improves soil physical characteristics such as structures, porosity and water-holding capacity through increased organic matter content of soil. FYM when applied in conjunction with biofertilizers, supplies energy to beneficial microorganisms including Azotobacter and PSB. Organic sources of nutrients applied to the preceding crop benefits the succeeding crop to a great extent (Hedge and Dwivedi, 1992). Azospirillum spp. have been identified mainly as rhizosphere bacteria.

They proliferate in the rhizosphere (soil fraction affected by root activities) of numerous plant species of many families. After establishing in the rhizosphere in sufficient numbers, they usually, but not always, promote the growth of the host plant (Bashan and Holguin 1997). The use of PSB is considered to increase the efficiency of native as well as applied phosphorus with the secretion of organic acids (Gaur, 1990). There is an urgent need of enhancing the availability of phosphate to crop, by use of PSB cultures. The INM, however, helps in maintaining the productivity of soil and improves fertilizeruse efficiency.

Thus, it economizes the use of chemical fertilizers by influencing the yield of kharif crop (Bejbaruha et al., 2009) Therefore, the present study was undertaken with a view to find out the efficient and economic combination of organic, inorganic fertilizers and biofertilizers under sorghum-chickpea cropping sequence for getting more yield and net returns under rainfed conditions.

\section{Materials and Methods}

The experiment was conducted at Sorghum Research Unit Dr.Panjabrao Deshmukh Kruhi Vidhyapeeth, Akola, Maharashtra, during the rainy (kharif) and winter (rabi) seasons of 2013-2015. Nine Nutrient application treatments (INM) were assessed during Kharif for Sorghum and in rabi chickpea was grown on same site same randomization without any RDF in three replication in RBD on clayey soil, having $\mathrm{pH}$ 8.32 and electrical conductivity $0.28 \mathrm{dS} / \mathrm{m}$.

It was medium in organic carbon $(0.53 \%)$, low in available nitrogen $(232 \mathrm{~kg} / \mathrm{ha})$, low in available phosphorus $(20.34 \mathrm{~kg} / \mathrm{ha})$ and high in available potassium $(365 \mathrm{~kg} / \mathrm{ha})$. The experiment was laid out in randomized block design and nine nutrient application treatments (INM) were assessed during Kharif for Sorghum and in rabi chickpea was grown without any RDF in three replication (Table 1) Recommended doses of inorganic fertilizers consisting of $80 \mathrm{~kg} \mathrm{~N}$ and $40 \mathrm{~kg}$ each of $\mathrm{P}_{2} \mathrm{O}_{5}$ and $\mathrm{K}_{2} \mathrm{O} /$ ha were applied to sorghum only and rabi Chickpea was grown on residual soil nutrients. For sorghum basal dose of $\mathrm{N}$ as per the treatment and remaining $\mathrm{P}$ and $\mathrm{K}$ was applied through chemical fertilizers. $\mathrm{N}$ was applied in 2 splits, half at sowing and remaining $\mathrm{N}$ was applied 30 days after sowing.

Nitrogen, phosphorus and potassium were applied through urea, single superphosphate and muriate of potash, respectively. The FYM and vermicompost were applied based on the nitrogen equivalent basis and nutrient requirement of sorghum and biofertilizers used in the form of seed inoculation were Azospirillum and phosphate-solubilizing bacteria. Sorghum (CSH-14) and chickpea (JAKI- 9218) were sown using seed rates of $7.5-10 \mathrm{~kg} / \mathrm{ha}$ and $75-85 \mathrm{~kg} / \mathrm{ha}$ with a spacing of $45 \mathrm{~cm} \mathrm{x} 15 \mathrm{~cm}$ and $30 \mathrm{~cm} \mathrm{\times} 10 \mathrm{~cm}$ for 
sorghum and chickpea respectively. Sorghum was sown in second fortnight of July and harvested during 1 st week of November. During rabi season, chickpea was grown on the residual nutrient source and none of the fertilizers were applied to it. Chick pea was sown in 2nd week of November and harvested in 1st week of March during each year of experimentation. The crop sequence received total rainfall of $946.4 \mathrm{~mm}$ in 2013-14, 623.6 $\mathrm{mm}$ in 2014-15 and $796.5 \mathrm{~mm}$ in 2015-16 during the crop growth periods. The data on yield of sorghum and chickpea were recorded. The data was analyzed statistically as per Panse and Sukhatme (1967). The monetary return was calculated on pooled mean basis.

\section{Results and Discussion}

The application of $75 \%$ RDN through inorganic fertilizer+25\% RDN through FYM+ seed treatment with microbial fertilizers $\mathrm{PSB}+$ Azospirillum recorded significantly higher grain as well as fodder yield however it was at par with $75 \%$ RDN through inorganic fertilizer+25\% RDN through vermicompost+ seed treatment with microbial fertilizers PSB+ Azospirillum. As a result of better soil conditions and moisture storage in soil integrated nutrient management treatments had recorded better crop growth and yield attributing characters than only inorganic fertilizer application resulted in to higher yield of grain as well as fodder of sorghum. Similarly significantly maximum Grain yield and dry fodder yield of chickpea was recorded with the residual effect the same treatment $\left(\mathrm{T}_{7}\right)$ which was at par with application of $75 \% \mathrm{RDN}$ through inorganic fertilizer+25\% RDN through vermicompost+ seed treatment with microbial fertilizers PSB+ Azospirillum $\left(\mathrm{T}_{8}\right)$. Significantly maximum sorghum equivalent yield(q/ha) was recorded with the application of $75 \%$ RDN through inorganic fertilizer+25\% RDN through FYM+ seed treatment with microbial fertilizers
PSB + Azospirillum $\left(\mathrm{T}_{7}\right)$. However, it was at par with $\left(\mathrm{T}_{8}\right)$ Results of long-tern fertilizer experiments further supported the beneficial role of farmyard manure in enhancing apparent use efficiency of fertilizer NPK added maintaining yield stability in multiple cropping systems (Nambiar 1994). The results clearly showed the favorable effect of combined application of manures ,fertilizers and biofertilizers than inorganic fertilizers applied alone.

\section{Economic Studies}

\section{Gross monetary Returns}

The pooled GMR (Rs/ha) of kharif sorghum, rabi chickpea and of system was significantly maximum with the application of $75 \% \mathrm{RDN}$ through inorganic fertilizer+25\% RDN through FYM+ seed treatment with microbial fertilizers PSB+ Azospirillum, however it was at par with $75 \%$ RDN through inorganic fertilizer+25\% RDN through vermicompost+ seed treatment with microbial fertilizers PSB+ Azospirillum. It might be attributed to higher yield levels in these treatments.

\section{Net monetary returns}

The pooled NMR (Rs/ha) of kharif sorghum, rabi chickpea and of system was significantly maximum with the application of $75 \%$ RDN through inorganic fertilizer+25\% RDN through FYM+ seed treatment with microbial fertilizers PSB+ Azospirillum and it was superior over all other treatments.

\section{B:C ratio of system}

The $\mathrm{B}: \mathrm{C}$ ratio of system was maximum with the application of $75 \%$ RDN through inorganic fertilizer+25\% RDN through FYM+ seed treatment with microbial fertilizers $\mathrm{PSB}+$ Azospirillum to kharif sorghum. 
Table.1 Treatment details (Kharif- Sorghum)

\begin{tabular}{|l|l|}
\hline T1 & 100\% RDN through inorganic fertilizer \\
\hline T2 & 50\% RDN through inorganic fertilizer+50\% RDN through FYM \\
\hline T3 & 75\% RDN through inorganic fertilizer+25\% RDN through FYM \\
\hline T4 & 50\% RDN through inorganic fertilizer+50\% RDN through vermicompost \\
\hline T5 & 75\% RDN through inorganic fertilizer+25\% RDN through vermicompost \\
\hline T6 & $\begin{array}{l}\text { 50\% RDN through inorganic fertilizer+25\% RDN through FYM+25\% RDN through } \\
\text { vermicompost }\end{array}$ \\
\hline T7 & $\begin{array}{l}\text { 75\% RDN through inorganic fertilizer+25\% RDN through FYM+ seed treatment with } \\
\text { microbial fertilizers PSB+ Azospirillum }\end{array}$ \\
\hline T8 & $\begin{array}{l}\text { 75\% RDN through inorganic fertilizer+25\% RDN through vermicompost+ seed } \\
\text { treatment with microbial fertilizers PSB+ Azospirillum }\end{array}$ \\
\hline T9 & $\begin{array}{l}\text { 75\% RDN through inorganic fertilizer+seed treatment with microbial fertilizers } \\
\text { PSB+Azospirillum }\end{array}$ \\
\hline
\end{tabular}

(Treatments were applied to Kharif Sorghum only and Rabi Chickpea was grown on residual soil nutrients.)

Table.2 Pooled Grain and Dry fodder yield (q/ ha)of sorghum and chickpea and Sorghum Equivalent Yield (q/ha) as influenced by different treatments

\begin{tabular}{|c|c|c|c|c|c|}
\hline Treatment details & $\begin{array}{r}\text { Grain al } \\
\text { yield } \\
\text { so }\end{array}$ & $\begin{array}{l}y \text { fodder } \\
\text { a) of } \\
\text { m. }\end{array}$ & $\begin{array}{l}\text { Grain a } \\
\text { yield }(q /\end{array}$ & $\begin{array}{l}\text { fodder } \\
\text { chickpea }\end{array}$ & $\begin{array}{l}\text { Sorghum } \\
\text { Equivalent } \\
\text { Yield }\end{array}$ \\
\hline N1:100\% RDN(IF) & 26.88 & 113.43 & 11.23 & 17.23 & 64.31 \\
\hline N2:50\% RDN(IF) +50\% RDN FYM & 27.25 & 113.85 & 13.22 & 18.75 & 71.31 \\
\hline N3:75\% RDN (IF) +25\% RDN FYM & 27.76 & 114.44 & 12.03 & 18.82 & 67.86 \\
\hline N4:50\% RDN (IF)+50\% RDN VC & 29.18 & 125.79 & 11.42 & 18.06 & 67.24 \\
\hline N5:75\% RDN(IF) +25\% RDN VC & 29.80 & 123.80 & 11.77 & 19.82 & 69.05 \\
\hline $\begin{array}{llll}\text { N6:50\% } & \text { RDN(IF) } & +25 \% & \text { RDN } \\
\text { FYM+25\% RDN VC } & & \end{array}$ & 25.80 & 112.68 & 11.62 & 17.91 & 64.54 \\
\hline $\begin{array}{l}\text { N7:75\% RDN(IF)+25\% RDN } \\
\text { FYM+ST(PSB+ Azspirillum) }\end{array}$ & 31.62 & 131.56 & 14.21 & 21.06 & 79.99 \\
\hline $\begin{array}{l}\text { N8:75\% RDN(IF) +25\% RDN ST } \\
\text { (PSB+ Azospirillum) }\end{array}$ & 31.14 & 124.14 & 13.04 & 19.27 & 75.59 \\
\hline $\begin{array}{l}\text { N9:75\% RDN(IF) + ST } \\
\text { Azospirillum) }\end{array}$ & 24.63 & 102.63 & 9.33 & 15.85 & 55.73 \\
\hline $\mathrm{SE}(\mathbf{m}) \pm$ & 0.48 & 1.02 & 0.58 & 0.63 & 2.04 \\
\hline CD P $=0.05$ & 1.37 & 2.87 & 1.65 & 1.77 & 5.78 \\
\hline
\end{tabular}

RDN: Recommended dose of nitrogen, FYM: Farm yard manure, VC: Vermicompost, ST:Seed Treatment,

IF:Inorganic fertilizer 
Table.3 Pooled GMR (Rs/ha) ,NMR(Rs/ha) and B:C Ratio of Sorghum, Chickpea and System as affected by different Treatments

\begin{tabular}{|c|c|c|c|c|c|c|c|c|}
\hline \multirow[t]{2}{*}{ Treatments } & \multicolumn{3}{|c|}{$\begin{array}{l}\text { GMR } \\
\text { (Rs/ha) }\end{array}$} & \multirow{2}{*}{$\begin{array}{c}\text { COC } \\
\text { System } \\
\text { (Rs/ha) }\end{array}$} & \multicolumn{3}{|c|}{ NMR(Rs/ha) } & \multirow{2}{*}{$\begin{array}{c}\text { B:C } \\
\text { Ratio } \\
\text { System }\end{array}$} \\
\hline & Sorghum & Chick pea & $\begin{array}{l}\text { System } \\
\text { GMR }\end{array}$ & & Sorghum & Chick pea & System NMR & \\
\hline N1:100\% RDN(IF) & 69479 & 36517 & 105996 & 33000 & 49979 & 23017 & 72996 & 2.21 \\
\hline $\begin{array}{l}\text { N2:50\% } \\
+\mathbf{5 0 \%} \text { RDN }\end{array}$ & 70159 & 42904 & 113063 & 41445 & 42213 & 29404 & 71617 & 1.73 \\
\hline $\begin{array}{l}\text { N3:75\% RDN } \\
+25 \% \text { RDN FYM }\end{array}$ & 71084 & 39136 & 110221 & 34567 & 50018 & 25636 & 75654 & 2.19 \\
\hline $\begin{array}{l}\text { N4:50\% } \\
\text { (IF)+50\% }\end{array}$ & 76089 & 37154 & 113243 & 35378 & 54211 & 23654 & 77865 & 2.20 \\
\hline $\begin{array}{l}\text { N5:75\% } \\
+25 \% \text { RDN VC }\end{array}$ & 76549 & 38375 & 114924 & 35409 & 54641 & 24875 & 79516 & 2.25 \\
\hline $\begin{array}{lr}\text { N6:50\% } & \text { RDN(IF) } \\
+25 \% & \text { RDN } \\
\text { FYM+25\% } & \text { RDN VC }\end{array}$ & 67650 & 37789 & 105439 & 36975 & 44175 & 24289 & 68463 & 1.85 \\
\hline $\begin{array}{l}\text { N7:75\% RDN(IF)+25 } \\
\% \text { RDN } \\
\text { FYM+ST(PSB+ } \\
\text { Azspirillum) }\end{array}$ & 82795 & 46170 & 128965 & 34817 & 61479 & 32670 & 94148 & 2.70 \\
\hline $\begin{array}{l}\text { N8:75\% RDN(IF) } \\
+25 \% \text { RDN ST } \\
\text { APSB+ } \\
\text { Azospirillum) }\end{array}$ & 80190 & 42366 & 122555 & 35659 & 58031 & 28866 & 86897 & 2.44 \\
\hline $\begin{array}{ll}\text { N9:75\% } & \text { RDN(IF) + } \\
\text { ST } & \text { (PSB+ } \\
\text { Azospirillum) } & \end{array}$ & 63345 & 30415 & 93760.4 & 32000 & 44845 & 16915 & 61760 & 1.93 \\
\hline $\mathrm{SE}(\mathbf{m}) \pm$ & 383 & 1881 & 1948 & - & 383 & 1881 & 1948 & - \\
\hline $\mathrm{CD} P=0.05$ & 1082 & 5319 & 5508 & - & 1082 & 5319 & 5508 & - \\
\hline
\end{tabular}


Nawale et. al., (2009) also recorded significantly highest value for nutrient uptake, gross returns, net returns and maximum value for benefit : cost ratio of succeeding chickpea with residual effect of $25 \% \mathrm{~N}$ through FYM $+25 \% \mathrm{~N}$ through vermicompost $+50 \% \mathrm{~N}$ through RDF applied to forage sorghum compared to the application of reduced or higher value of RDF in combination with the organic manures or alone inorganic fertilizer to preceding forage sorghum.

Thus, it can be concluded that, integration of inorganic fertilizers (75 per cent RDF) and organic manures (FYM) @ 2.5 ton per ha and seed treatment with biofertilizers to sorghum crop followed by chickpea without application of recommended dose is the best proposition to get the high productivity and profitability of sorghum and chickpea sequence. Similar results were obtained by Gawai and Pawar (2006).

\section{References}

Bashan, Y., and Holguin, G. 1997. Azospirillum-plant relationships: environmental and physiological advances . Can. J. Microbiol. 43: $103-$ 121.

Bejbaruha, R., Sharma, R.C. and Banik, P. 2009. Direct and residual effect of organic and inorganic sources of nutrients on rice based cropping system in the sob-humid tropics of India.

Gaur, A. C. (1990): Phosphate solubilizing microorganisms as biofertilizers. Omega Scientific Publishers, New Delhi, 198p. Illmer, P.

Gawai P.P. and Pawar V.S. 2006. Integrated nutrient management in sorghum (Sorghum bicolor)-chickpea (Cicer arietinum) cropping sequence under irrigated conditions.Indian $\mathbf{J}$ Agronomy.51(1):17-20.

Hegde,D.M. and Dwivedi,B.S.1992.Nutrient management in rice-wheat cropping system in India.Fertilizer News. 37:2741

Nambiar K K M. 1994. Soil Fertility and Crop Productivity under Long-term, Fertilizer Use in India. Indian Council of Agricultural Research, New Delhi.

Nawale S.S., Pawar A.D., Lambade B.M. and N.S. Ugale.2009.Yield Maximization Of Chick Pea Through INM Applied To Sorghum-Chickpea Cropping Sequence Under Irrigated Condition . Legume Res., 32 (4) : 282-285.

Panse, V.G. and Sukhatme, P.V. (1967). Statistical Methods for Agricultural Workers, ICAR, New Delhi, pp. 359.

Wei Wua and Baoluo Ma.(2015).Integrated nutrient management (INM) for sustaining crop productivity and reducing environmental impact: A review. Science of The Total Environment. 512-513 (15): 415-427

\section{How to cite this article:}

Seema M. Nemade, N. B. Mohod, G. J. Bhagat, V. R. Thakur, D. T. Dhule and Ganvir M. M. 2020. Economics of Sorghum - Chickpea Cropping System as Affected by Integrated Nutrient Management (INM) under Rainfed Conditions. Int.J.Curr.Microbiol.App.Sci. 9(03): 29572962. doi: https://doi.org/10.20546/ijcmas.2020.903.339 